\author{
KATARZYNA PADUCH ${ }^{1}$ \\ Wydział Nauk Historycznych \\ Uniwersytet Kardynała Stefana Wyszyńskiego, Warszawa \\ ORCID: 0000-0002-5262-5577
}

\title{
STAN BADAŃ NAD REFORMACJĄ NA MAZOWSZU - ZARYS PROBLEMATYKI I POSTULATÓW BADAWCZYCH ${ }^{2}$
}

\section{State of research on the Reformation in Mazovia - outline of the problem and research postulates}

\section{Abstract}

This article aims to present the state of research on the reformation in Mazovia after 1945 to modern times on various levels. Among the historians investigating the process of permeating Protestant religions in Mazovia, several research problems can be distinguished. The first of these may be the activities of the diocese of Płock and the cathedral chapter towards the reforming in Mazovia and the initiatives taken by the Płock bishops both during the Reformation and the Counter-Reformation period. Another research problem is the development of Protestant denominations in specific lands of Mazovia. Historians undertaking the problem of reformation in Mazovia also dealt with the book during the Reformation in Mazovia.

Keywords: Mazovia, reformation, Counter-Reformation, Protestantism, Calvinism, Lutheranism

\section{Streszczenie}

Niniejszy artykuł ma na celu przedstawienie stanu badań nad reformacją na Mazowszu po 1945 roku do czasów współczesnych na różnych płaszczyznach. Wśród historyków badających proces przenikania religii protestanckich na Mazowszu można wyróżnić kilka problemów badawczych. Pierwszy z nich to działania diecezji płockiej i kapituły katedralnej wobec rozwijającej się na Mazowszu reformacji oraz inicjatywy podejmowane przez biskupów płockich zarówno w okresie reformacji, jak i w okresie kontrreformacji. Kolejny problem badawczy to rozwój wyznań protestanckich na konkretnych ziemiach Mazowsza.

\footnotetext{
1 Dr Katarzyna Paduch - historyk, absolwentka Uniwersytetu Kardynała Stefana Wyszyńskiego, obecnie asystent w Instytucie Historii UKSW. Zainteresowania naukowe: historia kultury w XVIII i XIX w., dzieje rodu Rzewuskich h. Krzywda, funkcjonowanie dóbr magnackich.E-mail: k.paduch@uksw.edu.pl.

2 Referat został wygłoszony podczas Ogólnopolskiej Konferencji Naukowej „Reformacja - Kontrreformacja Reforma Katolicka na Mazowszu”, która odbyła się dnia 19 października 2017 r. w Domu Polonii w Pułtusku.
} 
Historycy podejmujący problem reformacji na Mazowszu zajęli się także książką w okresie reformacji na Mazowszu.

Słowa kluczowe: Mazowsze, reformacja, kontrreformacja, protestantyzm, kalwinizm, luteranizm

$\mathrm{N}$ a początku XVI wieku Marcin Luter zapoczątkował ruch religijno-społeczny, który zapisał się w historiografii jako reformacja. Działania podjęte przez niemieckiego duchownego były reakcją na negatywne zjawiska, które ogarnęły struktury Kościoła katolickiego. Niniejszy artykuł ma na celu przedstawienie stanu badań nad reformacją na Mazowszu po 1945 roku do czasów współczesnych na różnych płaszczyznach.

Badaniem przenikania religii protestanckich na Mazowsze zajęło się kilku badaczy w latach 80. XX wieku. Warto zwrócić uwagę na prace Włodzimierza Budki: Przejawy reformacji w miastach Mazowsza (1526-1548)³, a także Przejawy reformacji na Mazowszu w latach 1548-1572, które ukazały się na łamach rocznika „Odrodzenie i Reformacja w Polsce”" w latach 80. XX wieku. W tym samym czasie w czasopiśmie „Notatki Płockie” Wacław Urban zaprezentował pracę Reformacja na Mazowszu . Również wtedy wyniki swoich badań nad protestantyzmem przedstawił także Roman Nir, prezentując m.in. artykuł Stanowisko biskupa Andrzeja Krzyckiego wobec luteranizmu, który ukazał się w „Studiach Płockich” w 1981 roku $^{6}$. Z kolei badaniem działalności władz diecezji płockiej w obliczu postanowień soboru trydenckiego zajęli się Wojciech Góralski ${ }^{7}$, Dariusz Kisiel ${ }^{8}$, a także Andrzej Rojewski ${ }^{9}$. Lata 90. XX wieku przyniosły nowe ustalenia na temat protestantyzmu na Mazowszu będące wynikiem badań m.in. Leszka Zygnera ${ }^{10}$, Waldemara Graczyka ${ }^{11}$, Pawła Fijałkowskiego ${ }^{12}$, a także Jolanty Choińskiej-Miki ${ }^{13}$. Badania nad recepcją religii protestanckich na Mazowszu kontynuowane są obecnie i doczekały się nowych badaczy. Wymienić w tym miejscu należy chociażby artykuł Aleksandry Sołtan Książka innowiercza na Mazowszu płockim

\footnotetext{
3 W. Budka, Przejawy reformacji w miastach Mazowsza (1526-1548), „Odrodzenie i Reformacja w Polsce”, 1983 , t. 28 , s 185-194.

4 Tenże, Przejawy reformacji na Mazowszu w latach 1548-1572, „Odrodzenie i Reformacja w Polsce”, 1985 , t. 30, s.143-177.

5 W. Urban, Reformacja na Mazowszu, „Notatki Płockie”, 1985, nr 2, s. 24-27.

6 R. Nir, Stanowisko biskupa Andrzeja Krzyckiego wobec luteranizmu, „Studia Płockie”, 1981, t. 9, s. 73-85.

7 W. Góralski, Diecezja płocka i jej synody w okresie potrydenckim: szkic do badań nad recepcja soboru trydenckiego w świetle ustawodawstwa synodów diecezjalnych, ,Studia Płockie”, 1986, t. 14, s. 159-186.

8 D. Kisiel, Recepcja reformy trydenckiej $w$ diecezji płockiej, „Studia Płockie”, 2000, t. 28, s. 187-206.

9 A. Rojewski, Formacja duchowieństwa archidiakonatu dobrzyńskiego w latach 1597-1609 i jej wptyw na przyjęcie posoborowej liturgii, „Studia Płockie”, 1976, t. 4, s. 23-54; tenże, Stan obiektów kulturowych i ich adaptacja do wymogów reformy trydenckiej w archidiakonacie dobrzyńskim w latach 1597-1609, „Studia Płockie”, 1980, t. 8, s. $179-213$.

10 L. Zygner, Reformacja w Mławie - przyczynek do dziejów reformacji na Północnym Mazowszu, „Notatki Płockie", 1995, nr 4, s. 19-20.

11 W. Graczyk, Husytyzm w diecezji płockiej w latach 1439-1463, „Studia Płockie”, 1996, t. 24, s. 167-177; tenże, Katolicy i protestanci na Mazowszu, w: Dzieje Mazowsza lata 1527-1794, t. 2, red. J. Tyszkiewicz, Pułtusk 2015, s. 312-318.

12 P. Fijałkowski, Początki protestantyzmu na pograniczu wielkopolsko-mazowieckim, „Notatki Płockie”, 1993, nr 2, s. 10-11.

13 J. Choińska-Mika, Sejmiki mazowieckie w dobie Wazów, Warszawa 1998, s. 129-142.
} 
w'sietle akt kapituły płockiej z lat 1547-1552, który ukazał się w „Roczniku Mazowieckim” w 2003 roku $^{14}$, pracę Jan Mironczuka Reformacja na Mazowszu Północnym (diecezja płocka) opublikowaną w 201615, a także publikację Patrycji Ewy Herod Okoliczności wydania dekretu antyluterańskiego 15 marca 1525 r. przez księcia mazowieckiego Janusza III, która ukazała się na łamach opracowania Polska i ziemie pruskie po pokoju toruńskim (1466 r.) w 2017 roku $^{16}$.

Historycy badający recepcję religii protestanckich na Mazowszu podejmują kilka problemów badawczych. Pierwszy omawia działalność diecezji płockiej i kapituły katedralnej wobec rozwijającej się na Mazowszu reformacji oraz inicjatyw podejmowanych przez biskupów płockich zarówno w okresie reformacji jak i w okresie kontrreformacji. Wyróżnić można także grupę historyków, którzy ukierunkowali swoje badania na przedstawienie przebiegu reformacji i rozwoju wyznań protestanckich na konkretnych ziemiach Mazowsza. Wśród powstałych prac można wyszczególnić także artykuły odnoszące się do recepcji poszczególnych religii protestanckich na Mazowszu, w których przedstawiono przedstawicieli protestanckich wyznań oraz innowiercze miejsca kultu. Historycy podejmujący problem reformacji na Mazowszu zajęli się także ważnym zagadnieniem, traktowanym do tej pory marginalnie, mianowicie książką w okresie reformacji. Wśród powstałych prac poświęconych reformacji na Mazowszu są i takie, które zajmują się problemem oddziaływania innych ziem oraz miejsc kultu innowierczego na strukturę wyznaniową ziemi mazowieckiej.

\section{Działalność diecezji płockiej i kapituły katedralnej}

Po wystąpieniu Marcina Lutra w 1517 roku prądy reformacyjne w małym jeszcze stopniu dotarły na teren diecezji płockiej. Eugeniusz Wiśniowski w swoim artykule Diecezja płocka u progu czasów nowożytnych zwraca uwagę, iż w osiem lat po wystąpieniu niemieckiego duchownego pod naciskiem biskupa płockiego Rafała Leszczyńskiego (1522-1527) książę Janusz III wydał dekret w 1525 roku zakazujący przyjmowania nauk Lutra oraz szerzenia dzieł luterańskich ${ }^{17}$. Z kolei próbę zahamowania religii protestanckich $\mathrm{w}$ diecezji płockiej podjął biskup płocki Andrzej Krzycki (1527-1535), który objął diecezję w marcu 1527 roku. Inicjatywy podejmowane przez Andrzeja Krzyckiego zmierzające do zahamowania recepcji luteranizmu przestawił Roman Nir we wspomnianym artykule Stanowisko biskupa Andrzeja Krzyckiego wobec luteranizmu ${ }^{18}$. Działalność wybitnego humanisty, biskupa Andrzeja Krzyckiego odnotował także w swojej publikacji wspomniany wcześniej Eugeniusz Wiśniowski ${ }^{19}$.

\footnotetext{
14 A. Sołtan, Książka innowiercza na Mazowszu płockim w świetle akt kapituly płockiej z lat 1547-1552, ,Rocznik Mazowiecki", 15/2003, s. 27-34.

15 J. Mironczuk, Reformacja na Mazowszu Pólnocnym (diecezja płocka), „Studia Theologica Pentecostalia”, 2016, nr 4, s. 71-91.

16 P.E. Herod, Okoliczności wydania dekretu antyluterańskiego 15 marca 1525 r. przez księcia mazowieckiego Janusza III, w: Polska i ziemie pruskie po pokoju toruńskim (1466 r.), red. D. Makiłła, Warszawa 2017, s. 131-144.

17 E. Wiśniowski, Diecezja płocka u progu czasów nowożytnych, „Studia Płockie”, 1975, t. 3, s. 122-123; Historia Kościoła w Polsce, t. 1: Do roku 1764, cz. 1: Do roku 1506, red. B. Kumor, Z. Obertyński, Poznań-Warszawa 1974, s. 52; K. Kowalska, Leszczyński Rafał (zm. 1527), w: Polski Słownik Biograficzny (dalej: PSB), t. 17, red. E. Rostworowski, Wrocław-Warszawa-Kraków 1972, s. 130-132.

18 R. Nir, Stanowisko biskupa Andrzeja Krzyckiego..., op. cit., s. 73-85; P. Nitecki, Krzycki Andrzej (1481-1537), w: Biskupi Kościoła w Polsce w latach 965-1999: słownik biograficzny, Warszawa 2000, k. 232.

19 E. Wiśniowski, op. cit., s. 122.
} 
Oprócz wspomnianej wyżej działalności antyreformacyjnej biskupa Krzyckiego, Roman Nir zwracał uwagę w swoim artykule Próba nawrócenia Melanchtona przez biskupa Andrzeja Krzyckiego na kolejną inicjatywę podejmowaną przez biskupa i wymierzoną w ruch reformacyjny, który w celu osłabienia działalności Lutra podjął próbę nawrócenia na katolicyzm jego współpracownika - Filipa Melanchtona (1497-1560) ${ }^{20}$.

Charakterystykę sytuacji w diecezji płockiej oraz działania podjęte przez kapitułę w obliczu recepcji wyznań reformacyjnych zamieścili w swoich pracach: Włodzimierz Budka ${ }^{21}$, Wacław Urban ${ }^{22}$, Leszek Zygner ${ }^{23}$,Waldemar Graczyk ${ }^{24}$, a także Jan Mironczuk ${ }^{25}$.

Badacze wspominają o procesach wytoczonych heretykom, zaznaczając, iż już wiosną 1526 roku odbyły się dwa procesy o herezję w Warszawie (oskarżenie krawca protestanta) oraz w Płocku (proces cześnika płockiego Jana Garwaskiego, który zatrudniał nauczyciela luteranina na dworze). W pracach wspomnianych historyków można znaleźć również informacje o okolicznościach procesów wytoczonych przez kapitułę płocką innowiercom w 1551 roku $^{26}$. Natomiast na temat działań kapituły płockiej podjętych od 1550 roku wobec szlachty szerzącej herezje wzmiankują w swoich pracach: Włodzimierz Budka, Wacław Urban, a także Waldemar Graczyk, pisząc, iż kapituła płocka podjęła działania związane z herezją wobec szlachty z ziemi dobrzyńskiej mianowicie Suszyckich i Chełmickich, a także rodziny Grzebskich z powiatu mławskiego ${ }^{27}$. Z kolei w pracy Jana Mironczuka można znaleźć zestawienie przygotowane na podstawie analizy prac wcześniej wspomnianych badaczy, poszerzone o nowe ustalenia, prezentujące przejawy reformacji wśród szlachty na obszarze diecezji płockiej w latach 50. XVI wieku².

Wspominani wielokrotnie Włodzimierz Budka, Wacław Urban, a także Jan Mironczuk zaznaczają, iż nieprzychylny wyznawcom wyznań protestanckich był także biskup płocki Andrzej Noskowski (1546-1567), który, mając na uwadze odrodzenie się katolicyzmu, sprowadził do Pułtuska jezuitów ${ }^{29}$. Na temat synodów diecezjalnych $(1551,1557,1565)$ oraz działalności biskupa Andrzeja Noskowskiego wspomina także w swym artykule Próba

\footnotetext{
20 R. Nir, Próba nawrócenia Melanchtona przez biskupa Andrzeja Krzyckiego, „Studia Płockie”, 1980, t. 8, s. 169177.

21 W. Budka, Przejawy reformacji w miastach..., op. cit., s. 185-194; tenże, Przejawy reformacji na Mazowszu..., op. cit., s. 143-177.

22 W. Urban, op. cit., s. 24-27.

23 L. Zygner, op. cit., s. 19-20.

24 W. Graczyk, Katolicy i protestanci..., op. cit., s. 312-318.

25 J. Mironczuk, Reformacja na Mazowszu..., op. cit., s. 71-81. Zob. także pracę: R. Lolo, Rubież czy prowincja? Kościót katolicki na Mazowszu w XVI-XVIII wieku, w: Mazowsze na pograniczu kultur w średniowieczu u nowożytności, red. M. Dygo, Pułtusk 2007, s. 109-121.

26 W. Budka, Przejawy reformacji w miastach ..., op. cit., s. 188-189;tenże, Przejawy reformacji na Mazowszu..., op. cit., s. 143-149; W. Urban, op. cit., s. 26; L. Zygner, op. cit., s. 19; W. Graczyk, Katolicy i protestanci..., op. cit., s. 313 .

27 W. Urban, op. cit., s. 26; W. Budka, Przejawy reformacji na Mazowszu..., op. cit., s. 146-148; W. Graczyk, Katolicy i protestanci..., op. cit., s. 313.

28 J. Mironczuk, Reformacja na Mazowszu..., op. cit., s. 78-79.

29 W. Urban, op. cit., s. 26; W. Budka, Przejawy reformacji na Mazowszu..., op. cit., s. 144; J. Mironczuk, Reformacja na Mazowszu..., op. cit., s. 86-87; M. Woźniakowa, Noskowski Andrzej (1492-1567), w: PSB, t. 23, red. E. Rostworowski, Wrocław-Warszawa-Kraków 1976, s. 218-223. Zob. także pracę: I. Gieysztorowa, A. Zahorski, A. Łukasiewicz, Cztery wieki Mazowsza: szkice z dziejów 1526-1914, Warszawa 1968, s. 96-97.
} 
potrydenckiej odnowy Kościoła płockiego na synodzie z 1586 r. Wojciech Góralski ${ }^{30}$. Kilka słów na temat działalności biskupa Noskowskiego można znaleźć także w pracy Wiesława Müllera Diecezja płocka od drugiej połowy XVI wieku do rozbiorów, która ukazała się na łamach czasopisma „Studia Płockie” w 1975 roku $^{31}$. Natomiast Waldemar Graczyk ustalił, iż biskup Andrzej Noskowski w postanowieniach synodu z 1557 roku, w uchwale Que causa heresum, zamieścił przyczynę szerzenia się protestantyzmu, jak zapisano, był nią niski poziom życia moralnego duchownych, a także zuchwałość ludzi świeckich ${ }^{32}$. Wspomniani badacze: Wojciech Góralski i Wiesław Müller, piszą również szerzej na temat synodu diecezji z 1586 roku, zwołanego za rządów biskupa Piotra Dunina-Wolskiego (1577-1590), $\mathrm{W}$ celu realizacji postanowień soboru trydenckiego w diecezji płockiej ${ }^{33}$. Z kolei Waldemar Graczyk w paragrafie Katolicy i protestanci na Mazowszu opublikowanym w monografii Dzieje Mazowsza lata 1527-1794 odnotowuje synod z 1589 roku, na którym to zapadło kilka istotnych postanowień dotyczących heretyków, m.in. biskup Piotr Dunin-Wolski nakazał duchownym informować o przypadkach osób podejrzanych o herezje ${ }^{34}$. Zaś w pracy Wiesława Müllera można znaleźć informacje na temat relacji o stanie diecezji płockiej biskupa Wojciecha Baranowskiego (1591-1607) wysłanej do Rzymu z 1595 roku, w której zawarł on wiadomości o innowiercach na terenie diecezji płockiejj3.

Odpowiedzią na groźbę rozprzestrzeniania się na Mazowszu wyznań protestanckich oraz próbą podjęcia reformy Kościoła były synody diecezjalne oraz wprowadzanie postanowień soboru trydenckiego (1545-1563) na ziemi mazowieckiej. Wprowadzanie postanowień reformy trydenckiej rozpoczął wspomniany biskup płocki Piotr Dunin-Wolski, zaś kontynuował biskup Wojciech Baranowski ${ }^{36}$. Badania na temat recepcji postanowień soboru trydenckiego w diecezji płockiej prowadził Wojciech Góralski, który swoje ustalenia przestawił w szeregu artykułów. Na uwagę zasługują prace: Diecezja płocka i jej synody w okresie potrydenckim: szkic do badań nad recepcja sobory trydenckiego w świetle ustawodawstwa synodów diecezjalnych, Odnowa duszpasterska $w$ diecezji płockiej $w$ świetle synodu z 1593 r., a także Ustawodawstwo synodalne diecezji ptockiej: stan badań oraz postulaty badawcze, opublikowane na łamach czasopisma „Studia Płockie” w latach 70. i 80. XX wieku ${ }^{37}$. Na temat realizacji postanowień soboru trydenckiego w diecezji płockiej pisali także Dariusz Kisiel ${ }^{38}$

\footnotetext{
30 W. Góralski, Próba potrydenckiej odnowy Kościoła płockiego na synodzie z 1586 r., „Studia Płockie”, 1983, t. 11, s. 235-238. Na temat synodów biskupa A. Noskowskiego W. Góralski pisze też w kolejnym artykule, Zob. tenże, Diecezja płocka i jej synody w okresie potrydenckim ..., op. cit., s. 175-177.

31 W. Müller, Diecezja płocka od drugiej połowy XVI wieku do rozbiorów, „Studia Płockie”, 1975, t. 3, s. $162-163$.

32 W. Graczyk, Katolicy i protestanci..., op. cit., s. 314.

33 W. Góralski, Próba potrydenckiej odnowy Kościoła płockiego..., 1983, t. 11, op. cit., s. 239-255; W. Müller, op. cit., s. 164-166; P. Nitecki, Wolski-Dunin Piotr (1530-1590), w: Biskupi Kościoła w Polsce w latach 965-1999: stownik biograficzny, Warszawa 2000, k. 493.

34 W. Graczyk, Katolicy i protestanci..., op. cit., s. 314.

35 W. Müller, op. cit., s. 166-169; A. Strzelecki, Baranowski Wojciech (1548-1615), w: PSB, t. 1, red. W. Konopczyński, Kraków 1935 s. 286-289.

36 W. Góralski, Diecezja płocka i jej synody w okresie potrydenckim..., op. cit., s. 165.

37 Ibidem, s. 159-186; W. Góralski, Odnowa duszpasterska $w$ diecezji płockiej w świetle synodu z 1593 r., „Studia Płockie", 1982, t. 10, s. 115-131;tenże, Ustawodawstwo synodalne diecezji ptockiej: stan badań oraz postulaty badawcze, „Studia Płockie”, 1979, t. 7, s. 174-186. Wymienić można także kolejną pracę: tenże, Synody płockie historia i współczesność, „Notatki Płockie”, 1991, nr 1, s. 21-24.

38 D. Kisiel, op. cit., s. 187-206.
} 
oraz Andrzej Rojewski ${ }^{39}$. Warto zwrócić uwagę, iż Dariusz Kisiel w swym artykule Recepcja reformy trydenckiej $w$ diecezji płockiej zawarł oddzielny paragraf dotyczący postanowień synodów względem heretyków ${ }^{40}$. Zestawienie prezentujące synody diecezji płockiej oraz ich stanowisko wobec reformacji w latach 1529-1593 zostało przygotowane przez Jana Mironczuka ${ }^{41}$. Natomiast na temat postanowień synodu diecezji płockiej z 1733 roku odbytego, w Pułtusku z inicjatywy biskupa Andrzeja Stanisława Załuskiego (1723-1736) ${ }^{42}$, przeciwko heretykom, wzmiankuje w swojej pracy Ostatni synod płocki w Polsce przedrozbiorowej Walenty Józef Sumracz ${ }^{43}$.

\section{Reformacja na ziemiach Mazowsza}

Próbę opisania reformacji na określonych ziemiach wschodzących w skład Mazowsza zajęli się Leszek Zygner ${ }^{44}$, Paweł Fijałkowski ${ }^{45}$, Włodzimierz Budka ${ }^{46}$, Gottfried Schramm ${ }^{47}$, a także Jan Mironczuk ${ }^{48}$. Pierwszy ze wspomnianych badaczy Leszek Zygner w artykule Reformacja w Mławie - przyczynek do dziejów reformacji na Północnym Mazowszu przedstawił przebieg reformacji w najdalej na północ wysuniętej części Mazowsza ${ }^{49}$. Z kolei na temat reformacji w miastach mazowieckich pisał Włodzimierz Budka, wspominając wyznawców wyznań reformacyjnych m.in. w Warszawie, Płocku, Łomży, a także Mławie ${ }^{50}$. Badania nad rozwojem protestanckich wyznań na pograniczu wielkopolsko-mazowieckim prowadził Paweł Fijałkowski, który w artykule Początki protestantyzmu na pograniczu wielkopolsko-mazowieckim zaprezentował główny ośrodek innowierczy na tym terenie - Brzeziny, a także osoby aktywnie wpływające na rozwój zboru kalwińskiego - Krzysztofa Lasockiego oraz mieszczanina, późniejszego kaznodzieję zboru - Grzegorza Pawła z Brzezin (ok. 1525-1591). Prezentując działalność Krzysztofa Lasockiego, autor wspominał także o założeniu przez niego parafii kalwińskiej we wsi Suserz pod Gąbinem ${ }^{51}$. Natomiast badania nad przebiegiem reformacji w centrum księstwa mazowieckiego prowadził Gottfried Schramm, który swoje ustalenia opublikował w pracy Problem reformacji w Warszawie w XVI wieku, która ukazała się na łamach „Przeglądu Historycznego” 1963 roku $^{52}$. Na uwagę badaczy zajmujących się

\footnotetext{
39 A. Rojewski, Formacja duchowieństwa archidiakonatu dobrzyńskiego ..., op. cit., s. 23-54; tenże, Stan obiektów kulturowych ..., op. cit., s. 179-213.

40 D. Kisiel, op. cit., s. 190-194.

41 J. Mironczuk, Reformacja na Mazowszu..., op. cit., s. 84-85.

42 Zob. P. Nitecki, Załuski Andrzej Stanisław (1695-1758), w: Biskupi Kościoła w Polsce w latach 965-1999: stownik biograficzny, Warszawa 2000, k. 506.

43 W.J. Surmacz, Ostatni synod płocki w Polsce przedrozbiorowej, „Studia Płockie”, 1976, t. 4, s. 160.

44 L. Zygner, op. cit., s. 19-20.

45 P. Fijałkowski P., Poczatki protestantyzmu..., op. cit., s. 10-11.

46 W. Budka, Przejawy reformacji w miastach..., op. cit., s. 188-194.

47 G. Schramm, Problem reformacji w Warszawie w XVI wieku, „Przegląd Historyczny”, 1963, z. 4, s. $557-571$.

48 J. Mironczuk, Reformacja na Mazowszu Pótnocnym (diecezja płocka), „Studia Theologica Pentecostalia”, 2016, nr 4, s. 71-91.

49 L. Zygner, op. cit., s. 19-20.

50 W. Budka, Przejawy reformacji w miastach..., op. cit., s. 188-194.

51 P. Fijałkowski P., Początki protestantyzmu..., op. cit., s. 10-11; Grzegorz Pawet z Brzezin (ok. 1525-1591),

w: Bibliografia literatury polskiej „,Nowy Korbut”, t. 2, red. R. Pollak, [Warszawa 1964], s. 55-60.

52 G. Schramm, op. cit., s. 557-571.
} 
dziejami Mazowsza zasługuje wspominana wcześniej praca Jana Mironczuka, w której zebrał on dotychczasowe ustalenia badaczy na temat wystąpień reformacyjnych w miastach na terenie Mazowsza za panowania Zygmunta Starego ${ }^{53}$.

\section{Wyznania protestanckie na Mazowszu}

Recepcja wyznań protestanckich jest wzmiankowana w pracach historyków badających dzieje Mazowsza. Informacje na temat wyznawców protestantyzmu, znanych przedstawicieli poszczególnych religii, a także miejsc kultu innowierców można znaleźć w pracach: Włodzimierza Budki ${ }^{54}$, Leszka Zygnera ${ }^{55}$, Wacława Urbana ${ }^{56}$, Pawła Fijałkowskiego ${ }^{57}$, Waldemara Graczyka $^{58}$, Michała Mariana Grzybowskiego ${ }^{59}$, Stanisława Litaka ${ }^{60}$, Jana Mironczuka ${ }^{61}$, a także Jolanty Choińskiej-Miki ${ }^{62}$.

I tak wspomniany Leszek Zygner, jak również Henryk Samsonowicz oraz Anna Supruniuk zgodnie zaznaczają w swoich badaniach, iż reformacja oddziaływała na nastroje społeczeństwa. W swoich pracach wspominają, iż 1525 roku miał miejsce protest społeczny, tzw. tumult warszawski pod hasłami reformacji ${ }^{63}$. Badacze recepcji wyznań protestanckich na Mazowszu ustalili miejsca oraz osoby wyznające reformacyjne wyznania. I tak Wacław Urban, Włodzimierz Budka, Paweł Fijałkowski w swych pracach zaznaczają, iż głównymi inicjatorami budowy zborów protestanckich w 2. połowie XVI wieku była rodzina Lasockich. Z inicjatywy przedstawicieli rodu Krzysztofa i Stanisława Lasockich powstały zbory w Suserzu pod Gąbinem oraz Zwoli ${ }^{64}$. Badacze zajmujący się zagadnieniem reformacji na Mazowszu ustalili także, iż na terenie prowincji działało 7 zborów: w Suserzu i Zwoli, w Warszawie założony przez kalwina, starostę warszawskiego - Jerzego Niemstę, w Sierzchowach koło

53 J. Mironczuk, Reformacja na Mazowszu..., op. cit., s. 75-77.

54 W. Budka, Przejawy reformacji w miastach ..., op. cit., s. 185-194; tenże, Przejawy reformacji na Mazowszu..., op. cit., s. 143-177.

55 L. Zygner, op. cit., s. 19-20.

56 W. Urban, op. cit., s. 24-27

57 P. Fijałkowski, Początki protestantyzmu..., op. cit., s. 10-11.

58 W. Graczyk, Husytyzm w diecezji płockiej..., op. cit., s. 167-177.

59 M.M. Grzybowski, Katolickie kaplice dworskie oraz miejsca kultu innowierców na Mazowszu w drugiej potowie XVIII wieku: materiały źródłowe z wizytacji kościelnych, „Studia Płockie”, 1982, t. 10, s. 261-292; tenże, Katolickie kaplice dworskie oraz miejsca kultu innowierców na Mazowszu w drugiej połowie XVIII wieku [c.d.]. materiały źródłowe z wizytacji kościelnych, „Studia Płockie”, 1985, t. 13, s. 262-293; tenże, Katolickie kaplice dworskie oraz miejsca kultu innowierców na Mazowszu w drugiej połowie XVIII wieku [c.d.]: materiały źródłowe $z$ wizytacji kościelnych, „Studia Płockie”, 1986, t. 14, s. 271-307; tenże, Struktura wyznaniowa ludności diecezji płockiej wedtug spisu Adama Michała Prażmowskiego z 1817 r., „Notatki Płockie”, 1981, nr 1, s. 15-19.

60 S. Litak, Parafie i ludność diecezji płockiej $w$ drugiej połowie XVIII w., „Studia Płockie”, 1975, t. 3, s. 227-245; tenże, Organizacja parafialna diecezji płockiej w drugiej połowie XVIII w., ,Zeszyty Naukowe Ostrołęckiego Towarzystwa Naukowego, 1999, nr 13, s. 29-35.

61 J. Mironczuk, Reformacja na Mazowszu..., op. cit., s.74-83.

62 J. Choińska-Mika, op. cit., s. 130-131.

63 L. Zygner, op. cit., s. 19; H. Samsonowicz, A. Supruniuk, Dzieje polityczne (połowa XIV-początek XVI w.), w: Dzieje Mazowsza, t. 1, red. H. Samsonowicz, Pułtusk 2006, s. 329; T. Strzebmosz, Tumult warszawski, Warszawa 1959, s. 9-135.

64 W. Urban, op. cit., s. 26-27; W. Budka, Przejawy reformacji na Mazowszu..., op. cit., s. 157-158; P. Fijałkowski, Poczatki protestantyzmu..., op. cit., s. 10-11; I. Kaniewska, Lasocki Krzysztof (zm. ok. 1580), w: PSB, t. 16, red. E. Rostworowski, Wrocław-Warszawa-Kraków 1971, s. 540-541; H. Kowalska, Lasocki Stanisław (ok. 1521-1563), w: PSB, t. 16, red. E. Rostworowski, Wrocław-Warszawa-Kraków 1971, s. 548-549. 
Rawy założony przez kasztelana oświęcimskiego - Krzysztofa Myszkowskiego, a także zbór w Niszczycach założony przez Niszczyckich oraz w Klewkach pod Przasnyszem, a także w Wierzbicku Chełmickich koło Lipna ${ }^{65}$.

Najwybitniejszym intelektualistą luterańskim z ziemi mazowieckiej, jak ustalili badacze reformacji na Mazowszu, był działający w połowie XVI wieku - Stanisław Murzynowski (Suszycki) z Suszyc (ok. 1528-1553). Historycy zajmujący się problem reformacji zwracają w swoich badaniach uwagę również na zwolenników reformacji pochodzących z Mazowsza, działających jednak poza jej granicami. Do tej grupy zaliczają: kalwina Andrzeja Praszmoviusa oraz luteranina Wawrzyńca Discordia - mieszczan przasnyskich, Stanisława Burbacha oraz Floriana Susligę pochodzących z patrycjatu warszawskiego, a także kalwina Stanisława z Ostrołęki, arianina Pawła z Wizny, Jakuba Przyłuskiego z Jeżowa oraz Stanisława Grzebskiego. Na terenie Małopolski i Litwy znani byli arianie mazowieccy: Stanisław Budzyński, Mikołaj Trzaska Wędrogowski oraz Szymon Budny (zm. ok. 1595) ${ }^{66}$. Z kolei wspominany już kilkakrotnie Jan Mironczuk w swojej pracy dotyczącej reformacji na Mazowszu rozszerzył przytoczone te informacje o krótkie noty na temat ich działalności ${ }^{67}$.

Włodzimierz Budka oraz Wacław Urban w swoich publikacjach prezentują postawę szlachty mazowieckiej wobec rozwijających się wyznań protestanckich. Wspomniani badacze ustalili, iż pierwszym protestanckim senatorem mazowieckim został w 1553 roku Jan Lutomirski (zm. 1567), a także iż w 2. połowie XVI wieku większość wojewodów i kasztelanów rawskich była wyznania protestanckiego ${ }^{68}$. Badacze zwracają także uwagę na zwolennika reformacji kasztelana płockiego - kalwina Anzelm Gostomskiego (ok. 1508-1588), a wskazują również, iż kasztelan radomski Andrzej Drzewicki oraz jego żona Katarzyna Pierścińska sprzyjali reformacyjnym nowinkom religijnym. Historycy odnotowują też przypadek szlachcianki Dłużniewskej, prawdopodobnie kasztelanki płockiej, która brała udział w nabożeństwach luterańskich ${ }^{69}$. Podsumowanie prezentujące dotychczasowy stan badań nad szlachtą mazowiecką przyjmującą wyznania reformacyjne znajduje się w pracy Jana Mironczuka ${ }^{70}$. Z kolei na temat postaw szlachty mazowieckiej na sejmach i sejmikach wobec różnowierców oraz wobec konfederacji warszawskiej pisze Jolanta Choińska-Mika w pracy Sejmiki mazowieckie $w$ dobie Wazów ${ }^{71}$. Natomiast Jan Dzięgielewski w publikacji

\footnotetext{
65 W. Urban, op. cit., s. 26-27; W. Budka, Przejawy reformacji na Mazowszu..., op. cit., s. 158; 176; J. Choińska-Mika, op. cit., s. 130-131, J. Mironczuk, Reformacja na Mazowszu..., op. cit., s. 80-81; W. Graczyk, Katolicy i protestanci..., op. cit., s. 314 .

${ }_{66}$ W. Urban, op. cit., s. 26; Stanisław Murzynowski (ok. 1528-1553), w: Bibliografia literatury polskiej „,Nowy Korbut”, t. 2, red. R. Pollak, [Warszawa 1964], s. 546-547; I. Gieysztor, Źle i dobrze o ludziach Mazowsza XVI-XVII w., „Notatki Płockie”, 1965, nr 3-4, s. 8; W. Budka, Przejawy reformacji na Mazowszu ..., op. cit., s. 149-161; I. Gieysztorowa, A. Zahorski, A. Łukasiewicz, Cztery wieki Mazowsza: szkice z dziejów 1526-1914, Warszawa 1968, s. 94-95; S. Kot, Budny Szymon (zm. ok. 1595), w: PSB, t. 3, red. W. Konopczyński, Kraków 1937, s. 96-99.

67 J. Mironczuk, Reformacja na Mazowszu..., op. cit., s. 81-83.

68 W. Budka, Przejawy reformacji na Mazowszu ..., op. cit., s. 148-149; W. Urban, op. cit., s. 26; H. Kowalska, Lutomirski Jan (zm. 1567), w: PSB, t. 18, red. E. Rostworowski, Wrocław-Warszawa-Kraków 1973, s. $139-141$.

69 W. Urban, op. cit., s. 27; W. Budka, Przejawy reformacji na Mazowszu ..., op. cit., s. 148-149; Gostomski Anzelm (ok. 1508-1588), w: Bibliografia literatury polskiej, t. 2, red. R. Pollak, [Warszawa 1964], s. 211-212.

70 J. Mironczuk, Reformacja na Mazowszu..., op. cit., s. 78-79.

71 J. Choińska-Mika, op. cit., s. 129-142.
} 
Wierność Kościołowi a kwestia ,,czarnej legendy” szlachty mazowieckiej przedstawił wyniki swoich badań na temat kwestii „fanatyzmu religijnego” szlachty mazowieckiej ${ }^{72}$.

Rozwój husytyzmu w diecezji płockiej w XV wieku był przedmiotem badań Waldemara Graczyka, który swoje ustalenia zaprezentował w artykule Husytyzm $w$ diecezji płockiej w latach 1439-1463, opublikowanym na łamach „Studiów Płockich” w 1996 roku. W publikacji zaprezentowano miejsca, w których zwolennicy husytyzmu działali, był to m.in. miasta Płock, Ciechanów oraz miejscowości Trąbin i Strzegowo. W pracy przedstawiono także działania podejmowane przez władze diecezji w celu zwalczania wyznawców husytyzmu ${ }^{73}$.

Informacje na temat miejsc kultu innowierców w połowie XVIII wieku na Mazowszu można znaleźć w artykułach Michała Mariana Grzybowskiego. Materiałem źródłowym były dla niego protokoły wizytacji generalnych i dekanalnych, które odbyły się za rządów biskupa Michała Jerzego Poniatowskiego (1773-1784) ${ }^{74}$ oraz biskupa Krzysztofa Szembeka $(1785-1797)^{75}$. Autor zestawił alfabetycznie parafie, a w ich obrębie dokonał chronologicznego uporządkowania, dzięki tak zaprezentowanym wynikom badań z łatwością można ustalić, w których parafiach znajdowały się miejsca kultu protestantów, a także ilu innowierców było na terenie poszczególnych parafii ${ }^{76}$.

W latach 70. XX wieku Stanisław Litak prowadził badania nad ludnością diecezji płockiej, w tym także jej strukturą wyznaniową. Wyniki swoich badań zaprezentował w artykule Parafie i ludność diecezji płockiej w drugiej połowie XVIII w., który ukazał się w „Studiach Płockich” w 1975 roku. Historyk ustalił, iż według spisu z 1776 roku było 5182 protestantów, co stanowi 1,5 procent ogółu ludności diecezji płockiej. W artykule zaznaczył również, iż w XVII i XVIII wieku najwięcej było protestantów na terenie ziemi dobrzyńskiej. Na pograniczu mazowiecko-pruskim w XVII i XVIII wieku zamieszkiwali przybyli z Prus Książęcych luteranie ${ }^{77}$. Kolejne informacje na temat struktury wyznaniowej diecezji płockiej można znaleźć w następnej publikacji Stanisława Litaka Organizacja parafialna diecezji płockiej w drugiej połowie XVIII w., w której poruszono kwestię osiedlania się protestantów w diecezji płockiej. W pracy tej autor zaznacza, iż na terenie Mazowsza reformacja się nie rozwijała, na terenie diecezji płockiej tylko ziemia dobrzyńska została objęta reformacyjnym ruchem religijnym. Natomiast luteranie zaczęli osiedlać się na Mazowszu po wojnach szwedzkich. Najwięcej było ich w ziemi dobrzyńskiej gdzie - jak zaznacza-stanowili od 12 (dekanat Lipno, Rypin) do 16 procent (Górzno). W pozostałej cześć Mazowsza było ich mniej. Zaś w niektórych dekanatach położonych wzdłuż granicy z Prusami Książęcymi liczba wyznawców luteranizmu nie przekraczała 2 procent $^{78}$.

\footnotetext{
72 J. Dzięgielewski, Wierność Kościołowi a kwestia „,czarnej legendy” szlachty mazowieckiej, w: Mazowsze Pótnocne. W poszukiwaniu tożsamości narodowej, społecznej i religijnej, red. J. Gołota, M. Truszczyński, Ostrołęka 2012, s. 10-11.

73 W. Graczyk, Husytyzm w diecezji płockiej..., op. cit., s. 167-177.

74 Zob. Z. Zielińska, Poniatowski Michał Jerzy (1736-1794), w: PSB, t. 27, red. E. Rostworowski, Wrocław-Warszawa-Kraków 1983, s. 455-471.

75 Zob. R. Butterwick, M. Czeppe, T. Żebrowski, Szembek Krzysztof Hilary (1723-1797), w: PSB, t. 48, red. A. Romanowski, Warszawa-Kraków 2012, s. 93-100.

76 M.M. Grzybowski, Katolickie kaplice dworskie..., 1982, t. 10, op. cit., s. 261-292; tenże, Katolickie kaplice dworskie..., 1985, t. 13, op. cit., s. 262-293; tenże, Katolickie kaplice dworskie..., 1986, t. 14, op. cit., s. 271-307.

77 S. Litak, Parafie i ludność diecezji płockiej..., op. cit., s. 234, 239-240.

78 Tenże, Organizacja parafialna diecezji płockiej..., op. cit., s. 33.
} 
Struktura wyznaniowa ludności diecezji płockiej w XIX wieku była również przedmiotem zainteresowań badawczych wspominanego wcześniej Michała Marcina Grzybowskiego, który swoje ustalenia przedstawił w pracy Struktura wyznaniowa ludności diecezji płockiej wedtug spisu Adama Michała Prażmowskiego z 1817 r. Autor na podstawie protokołu wizytacyjnego diecezji płockiej zarządzonej przez biskupa Adama Michała Prażmowskiego $(1817-1836)^{79}$ w 1817 roku przedstawił strukturę wyznaniową diecezji, prezentując wyniki analizy historycznej w tabelach, uwzględniających strukturę wyznaniową w parafiach, a także podając liczbę katolików, protestantów oraz Żydów ${ }^{80}$.

Z kolei szczegółowe wyliczenia na temat liczby protestantów w Płocku w kolejnym stuleciu można znaleźć w artykule Krzysztofa Kłodawskiego Struktura wyznaniowa mieszkańców Płocka $w$ XIX i początkach XX wieku: (w świetle rejestracji urzędowej) ${ }^{81}$. Autor zaznacza, iż największy spadek zanotowali protestanci (luteranie i kalwini) w strukturze wyznaniowej Płocka, z liczby około 10 procent na początku XIX wieku, do 5, a nawet 3 procent w połowie XIX wieku. Przed wybuchem I wojny światowej ich liczba wynosiła 2 procent $^{82}$. Początki funkcjonowania parafii luterańskiej w Płocku, przyczyny i kierunki migracji luteran w okolice Płocka, a także rozwój terytorium oraz wewnętrzną organizację parafii luterańskiej przedstawił Kłodawski w artykule Imigracja luteran $w$ okolice Płocka i jej wpływ na powstanie i rozwój terytorium parafii ewangelicko-augsburskiej w Płocku, który ukazał się na łamach czasopisma „Notatki Płockie” w 2001 roku $^{83}$.

Na temat kościoła ewangelickiego parafii p.w. Świętej Trójcy w Warszawie interesujące informacje można znaleźć w opracowaniu Jubileusz Parafii Ewangelicko-Augsburskiej Świętej Trójcy w Warszawie 1581-1781-1981, powstałym pod redakcją Stanisława Adamskiego ${ }^{84}$. Z kolei badania dotyczące ewangelików na terenie Mazowsza w XIX i XX wieku były przedmiotem zainteresowań naukowych Jana Mironczuka, który swoje ustalenia przedstawił w artykule Rzymskokatoliccy a inne wyznania chrześcijańskie w powiece ostrołęckim ${ }^{85}$ oraz pracy powstałej we współpracy z Elżbietą Mironczuk Starsze ,,sekty” protestanckie na Mazowszu i pograniczu mazurskim do I wojny światowej ${ }^{86}$.

\section{Książka innowiercza na Mazowszu}

Do zjednywania sobie większego grona wyznawców protestanckich wykorzystywano książkę, będącą wówczas nośnikiem informacji oraz doktryn wiary nowych wyznań. Historycy

\footnotetext{
79 Zob. M. Manteufflowa, Prażmowski Adam Michał (1764-1836), w: PSB, t. 28, red. E. Rostworowski, Wrocław-Warszawa-Kraków 1984, s. 371-374.

80 M.M. Grzybowski, Struktura wyznaniowa ludności diecezji płockiej..., op. cit., s. 15-19.

${ }^{81}$ K. Kłodawski, Struktura wyznaniowa mieszkańców Płocka w XIX i początkach XX wieku: (w świetle rejestracji urzędowej), „Notatki Płockie”, 2003, nr 4, s. 17-21.

82 Tamże, s. 17.

${ }^{83}$ K. Kłodawski, Imigracja luteran w okolice Płocka i jej wptyw na powstanie i rozwój terytorium parafii ewangelicko-augsburskiej w Płocku, „Notatki Płockie”, 2001, t. 46, nr 3, s. 10-17.

${ }^{84}$ Jubileusz Parafii Ewangelicko-Augsburskiej Świętej Trójcy w Warszawie 1581-1781-1981, red. S. Adamski, Warszawa [1985], s. 1-141.

85 J. Mironczuk, Rzymskokatolicy a inne wyznania chrześcijańskie w powiecie ostrołęckim, „Zeszyty Naukowe Ostrołęckiego Towarzystwa Naukowego", 2007, nr 21, s. 75-101.

${ }^{86}$ E. Mironczuk, J. Mironczuk, Starsze ,sekty” protestanckie na Mazowszu i pograniczu mazurskim do I wojny światowej, ,Zeszyty Naukowe Ostrołęckiego Towarzystwa Naukowego”, 2006, nr 20, s. 63-76.
} 
Leszek Zygner, Eugeniusz Wiśniowski, a także Patrycja Ewa Herod w swoich publikacjach wspominają, iż w celu ograniczenia reformacji na Mazowszu książę mazowiecki Janusz III wydał dekret w 1525 roku, pod naciskiem biskupa płockiego Stanisława Leszczyńskiego, w którym zakazywał w całym Księstwie Mazowieckim, w tym także w Warszawie posiadać, czytać, przechowywać księgi luterańskie, również w innych językach. Za posiadanie dzieł luterańskich lub wyznawanie luteranizmu groziła kara śmierci i konfiskata całego majątku na rzecz księcia ${ }^{87}$.

Z kolei Włodzimierz Budka zwraca uwagę w swym artykule, iż biskupi płoccy sprowadzali drukarzy do Pułtuska w celu upowszechniania dzieł katolickich wydawanych w języku polskim oraz w języku łacińskim. W Pułtusku, prawdopodobnie na zaproszenie biskupa Andrzeja Krzyckiego, działał w latach 30. XVI wieku drukarz krakowski Jan Sandecki (zwany też Małecki), zaś w Łowiczu w 2. połowie XVI wieku pracował przez kilka lat Stanisław Murmeliusz $^{88}$. Badacze książki innowierczej na Mazowszu znajdą interesujące informacje $\mathrm{w}$ innym artykule tego autora, który - przedstawiając okoliczności procesu szlachcica, właściciela młyna w Płocku, oskarżonego o herezję Pawła Dąbrowskiego, wymienia szczegółowo, jakie dzieła innowiercze zostały mu skonfiskowane w 1533 roku $^{89}$.

O pierwszych protestanckich woluminów na Mazowszu Zachodnim wspomina Paweł Fijałkowski w swym artykule „Polska książa ewangelicka”-wystawa w Miejskiej Bibliotece Publicznej w Sochaczewie, pisząc, iż wiosną 1450 roku husytę Jana z Bolimowa oskarżono o posiadanie heretyckich dzieł ${ }^{90}$. Z kolei wspomniany wcześniej Wojciech Góralski w swoich pracach odnotowuje kilka informacji na temat drogi przenikania ksiąg innowierczych na teren Mazowsza, wskazując, iż w połowie XVI wieku do Płocka przyjeżdżali regularnie księgarze z Poznania oraz Niemiec, przywożąc prace z zakresu literatury reformacyjnej. W celu ograniczenia tych praktyk kapituła katedralna wydała polecenie cenzurowania przywożonych dzieł ${ }^{91}$. Z kolei Adam Rojewski w artykule Formacja duchowieństwa archidiakonatu dobrzyńskiego w latach 1597-1609 i jej wplyw na przyjęcie posoborowej liturgii porusza zagadnienie szesnastowiecznych przepisów synodalnych dotyczących księgozbiorów parafialnych i przywołuje postanowienia władz diecezji dotyczące czytania i posiadania odpowiednich ksiąg teologicznych mających ułatwiać duchownym m.in. wyjaśnianie Ewangelii i zwalczanie herezji ${ }^{92}$. W 2003 roku w „Roczniku Mazowieckim” opublikowana została praca Aleksandry Sołtan zatytułowana Książka innowiercza na Mazowszu płockim $w$ świetle akt kapituły płockiej z lat 1547-1552. Autorka dokonała w niej analizy historycznej

\footnotetext{
87 L. Zygner, op. cit., s. 19; E. Wiśniowski, op. cit., s. 122-123. P.E. Herod, op. cit., s. 131-144. Zob. B. Sobol, O zaginionym druku mazowieckiego dekretu przeciwko luteranom z 1525 r., „Przegląd Historyczny”, 1959, t. 50, z. 1, s. 81-85.

88 W. Budka, Przejawy reformacji na Mazowszu..., op. cit., s. 161-162; Drukarze dawnej Polski od XV do XVIII wieku, t. 3 cz. 2: Mazowsze z Podlasiem, opr. K. Korotajowa, A. Endzel, J. Krauze-Karpińska, J. Szczepaniec, Warszawa 2001, s. 188-189, 314.

89 Tenże, Przejawy reformacji na Mazowszu..., op. cit., s. 144-146.

90 P. Fijałkowski, „Polska ksiązka ewangelicka” - wystawa w Miejskiej Bibliotece Publicznej w Sochaczewie, „Notatki Płockie”, 1994, nr 2, s. 49.

91 W. Góralski, Próba potrydenckiej..., op. cit., s. 234; tenże, Diecezja płocka i jej synody w okresie potrydenckim..., op. cit., s. 164.

92 A. Rojewski, Formacja duchowieństwa archidiakonatu dobrzyńskiego w latach 1597-1609 i jej wplyw na przyjęcie posoborowej liturgii, „Studia Płockie”, 1976, t. 4, s. 44-50.
} 
XVI-wiecznych akt kapituły płockiej pod kątem obiegu, recepcji oraz zwalczania książki innowierczej przez kapitułę płocką ${ }^{93}$.

\section{Oddziaływania innych ziem oraz miejsc kultu innowierczego na strukturę wyzna- niową Mazowsza}

Badacze wyznań reformacyjnych na Mazowszu zaznaczają w swych pracach, iż na strukturę wyznaniową Mazowsza oddziaływały protestanckie Prusy Książęce oraz ariański Węgrów, położony na granicy południowego Mazowsza i Podlasia. Na temat zboru ariańskiego w Węgrowie założonego w 1558 roku przez Jana Kiszkę oraz jego żonę Annę z Radziwiłłów Kiszczynę, jak również o działalności tego ośrodka, pisali: Stefan Gruszecki w artykule Węrów kolebka arianizmu polskiego ${ }^{94}$, Józef Kazimierski ${ }^{95}$, a także Tadeusz Wyszomirski w pracy Z przeszłości zboru protestanckiego w Węrowie w XVII i XVIII wieku ${ }^{96}$. Z kolei Wacław Urban, a także Leszek Zygner, zwracają w swoich pracach uwagę na oddziaływanie Prus Książęcych na teren północnego Mazowsza, a w szczególności okolic Mławy ${ }^{97}$.

\section{Zakończenie}

Reformacja na Mazowszu jak dotąd nie doczekała się badacza, który podjąłby próbę całościowego zebrania dotychczasowych ustaleń historyków, skonfrontowania oraz porównania ich z przebiegiem reformacji na terenie innych ziem Korony, a także podjąłby próbę nowych badań, których wynikiem byłoby całościowe opracowanie oraz zaprezentowanie przebiegu reformacji, a także kontrreformacji na Mazowszu na wielu płaszczyznach, chociażby tych wskazanych w niniejszym artykule, ze szczególnym uwzględnieniem oddziaływania prądów reformacyjnych na szeroko pojętą kulturę Mazowsza. Zebranie wyników badań pod kątem zagadnień wskazanych przez autorkę pozwoli w znacznym stopniu uzupełnić stan wiedzy na temat reformacji oraz kontrreformacji na Mazowszu.

\section{Bibliografia}

Budka W., Przejawy reformacji na Mazowszu w latach 1548-1572, „Odrodzenie i Reformacja", 1985, t. 30, s. 143-177.

Budka W., Przejawy reformacji w miastach Mazowsza (1526-1548), „Odrodzenie i Reformacja w Polsce", 1983, t. 28, s. 185-194.

Butterwick R., Czeppe M., Żebrowski T., Szembek Krzysztof Hilary (1723-1797), w: Polski Słownik Bibliograficzny (dalej: PSB), t. 48, red. A. Romanowski, Warszawa-Kraków 2012, s. 93-100.

Choińska-Mika J., Sejmiki mazowieckie w dobie Wazów, Warszawa 1998.

93 A. Sołtan, op. cit., s. 27-34.

94 S. Gruszecki, Węgrów kolebką arianizmu polskiego, „Rocznik Mazowiecki”, 6/1976, s. 315-324.

95 J. Kazimierski, Z dziejów Węgrowa w XV-XVII wieku, „Rocznik Mazowiecki”, 3/1970, s. 267-282.

96 T. Wyszomirski, Z przeszłości zboru protestanckiego $w$ Węrowie w XVII i XVIII wieku, ,Odrodzenie i Reformacja w Polsce", 1959, t. 4, s. 137-155.

97 W. Urban, op. cit., s. 26-27. L. Zygner, op. cit., s. 19-20. 
Drukarze dawnej Polski od XV do XVIII wieku, t. 3, cz. 2: Mazowsze z Podlasiem, opr. K. Korotajowa, A. Endzel, J. Krauze-Karpińska, J. Szczepaniec, Warszawa 2001, s. 188-189, 314.

Dzięgielewski J., Wierność Kościołowi a kwestia ,czarnej legendy” szlachty mazowieckiej, w: Mazowsze Pólnocne. W poszukiwaniu tożsamości narodowej, społecznej i religijnej, red. J. Gołota, M. Truszczyński, Ostrołęka 2012, s. 7-12.

Fijałkowski P., ,,Polska ksiażka ewangelicka”-wystawa w Miejskiej Bibliotece Publicznej w Sochaczewie, „Notatki Płockie”, 1994, nr 2, s. 49-50.

Fijałkowski P., Poczatki protestantyzmu na pograniczu wielkopolsko-mazowieckim, „Notatki Płockie", 1993, nr 2, s. 10-11.

Gieysztor I., Źle i dobrze o ludziach Mazowsza XVI-XVII w., „Notatki Płockie”, 1965, nr 3-4, s. $5-13$.

Gieysztorowa I., Zahorski A., Łukasiewicz A., Cztery wieki Mazowsza: szkice z dziejów 1526-1914, Warszawa 1968.

Gostomski Anzelm (ok. 1508-1588), w: Bibliografia literatury polskiej „,Nowy Korbut”, t. 2, red. R. Pollak, [Warszawa 1964], s. 211-212.

Góralski W., Diecezja płocka i jej synody w okresie potrydenckim: szkic do badań nad recepcja soboru trydenckiego $w$ świetle ustawodawstwa synodów diecezjalnych, „Studia Płockie", 1986, t. 14, s. 159-186.

Góralski W., Odnowa duszpasterska $w$ diecezji płockiej $w$ świetle synodu z 1593 r., „Studia Płockie", 1982, t. 10, s. 115-131.

Góralski W., Próba potrydenckiej odnowy Kościoła płockiego na synodzie z 1586 r., „Studia Płockie", 1983, t. 11, s. 229-255.

Góralski W., Synody płockie - historia i współczesność, „Notatki Płockie”, 1991, nr 1, s. 21-24.

Góralski W., Ustawodawstwo synodalne diecezji płockiej: stan badań oraz postulaty badawcze, „Studia Płockie”, 1979, t. 7, s. 174-186.

Graczyk W., Husytyzm w diecezji płockiej w latach 1439-1463, „Studia Płockie”, 1996, t. 24, s. $167-177$.

Graczyk W., Katolicy i protestanci na Mazowszu, w: Dzieje Mazowsza lata 1527-1794, t. 2, red. J. Tyszkiewicz, Pułtusk 2015, s. 312-318.

Gruszecki S., Wegrów kolebką arianizmu polskiego, „Rocznik Mazowiecki”, 6/1976, s. 315-324.

Grzegorz Pawet z Brzezin (ok. 1525-1591), w: Bibliografia literatury polskiej „,Nowy Korbut”, t. 2, red. R. Pollak, [Warszawa 1964], s. 55-60.

Grzybowski M.M., Katolickie kaplice dworskie oraz miejsca kultu innowierców na Mazowszu $w$ drugiej połowie XVIII wieku [c.d.]: materiały źródłowe z wizytacji kościelnych, „Studia Płockie", 1985, t. 13, s. 262-293.

Grzybowski M.M., Katolickie kaplice dworskie oraz miejsca kultu innowierców na Mazowszu w drugiej połowie XVIII wieku: materiały źródłowe z wizytacji kościelnych, „Studia Płockie", 1982, t. 10, s. 261-292.

Grzybowski M.M., Katolickie kaplice dworskie oraz miejsca kultu innowierców na Mazowszu $w$ drugiej połowie XVIII wieku [c.d.]: materiały źródłowe z wizytacji kościelnych, „Studia Płockie", 1986, t. 14, s. 271-307.

Grzybowski M.M., Struktura wyznaniowa ludności diecezji płockiej wedtug spisu Adama Michała Prażmowskiego z 1817 r., „Notatki Płockie”, 1981, nr 1, s. 15-19. 
Herod P.E., Okoliczności wydania dekretu antyluterańskiego 15 marca 1525 r. przez księcia mazowieckiego Janusza III, w: Polska i ziemie pruskie po pokoju toruńskim (1466 r.), red. D. Makiłła, Warszawa 2017, s. 131-144.

Historia Kościoła $w$ Polsce, t. 1: Do roku 1764, cz. 1: Do roku 1506, red. B. Kumor, Z. Obertyński, Poznań-Warszawa 1974.

Jubileusz Parafii Ewangelicko-Augsburskiej Świętej Trójcy w Warszawie 1581-1781-1981, red. S. Adamski, Warszawa [1985].

Kaniewska I., Lasocki Krzysztof (zm. ok. 1580), w: PSB, t. 16, red. E. Rostworowski, Wrocław-Warszawa-Kraków 1971, s. 540-541.

Kazimierski J., Z dziejów Węrowa w XV-XVII wieku, „Rocznik Mazowiecki”, 3/1970, s. 267-282.

Kisiel D., Recepcja reformy trydenckiej $w$ diecezji płockiej, „Studia Płockie”, 2000, t. 28, s. 187-206.

Kłodawski K., Imigracja luteran w okolice Płocka i jej wptyw na powstanie i rozwój terytorium parafii ewangelicko-augsburskiej w Płocku, „Notatki Płockie”, 2001, t. 46, nr 3, s. $10-17$.

Kłodawski K., Struktura wyznaniowa mieszkańców Płocka w XIX i początkach XX wieku: (w świetle rejestracji urzędowej), „Notatki Płockie”, 2003, nr 4, s. 17-21.

Kot S., Budny Szymon (zm. ok. 1595), w: PSB, t. 3, red. W. Konopczyński, Kraków 1937, s. 96-99.

Kowalska H., Lasocki Stanistaw (ok. 1521-1563), w: PSB, t. 16, red. E. Rostworowski, Wrocław-Warszawa-Kraków 1971, s. 548-549.

Kowalska H., Lutomirski Jan (zm. 1567), w: PSB, t. 18, red. E. Rostworowski, Wrocław-Warszawa-Kraków 1973, s. 139-141.

Kowalska K., Leszczyński Rafał (zm. 1527), w: PSB, t. 17, red. E. Rostworowski, Wrocław-Warszawa-Kraków 1972, s. 130-132.

Litak S., Organizacja parafialna diecezji płockiej $w$ drugiej połowie XVIII w., „Zeszyty Naukowe Ostrołęckiego Towarzystwa Naukowego, 1999, nr 13, s. 29-35.

Litak S., Parafie i ludność diecezji płockiej w drugiej połowie XVIII w., „Studia Płockie”, 1975 , t. 3, s. 227-245.

Lolo R., Rubież czy prowincja? Kościół katolicki na Mazowszu w XVI-XVIII wieku, w: Mazowsze na pograniczu kultur w średniowieczu u nowożytności, red. M. Dygo, Pułtusk 2007, s. 109-121.

Manteufflowa M., Prażmowski Adam Michał (1764-1836), w: PSB, t. 28, red. E. Rostworowski, Wrocław-Warszawa-Kraków 1984, s. 371-374.

Mironczuk E., Mironczuk J., Starsze ,sekty” protestanckie na Mazowszu I i pograniczu mazurskim do I wojny światowej, ,Zeszyty Naukowe Ostrołęckiego Towarzystwa Naukowego", 2006, t. 20, s. 63-76.

Mironczuk J., Reformacja na Mazowszu Północnym (diecezja płocka), „Studia Theologica Pentecostalia", 2016, nr 4, s. 71-91.

Mironczuk J., Rzymskokatolicy a inne wyznania chrześcijańskie w powiece ostrołęckim, „Zeszyty Naukowe Ostrołęckiego Towarzystwa Naukowego, 2007, nr 21, s. 75-101.

Müller W., Diecezja płocka od drugiej połowy XVI wieku do rozbiorów, „Studia Płockie, 1975 , t. 3, s. $153-226$. 
Murzynowski Stanisław (ok. 1528-1553), w: Bibliografia literatury polskiej, t. 2, red. R. Pollak, [Warszawa 1964], s. 546-547.

Nir R., Próba nawrócenia Melanchtona przez biskupa Andrzeja Krzyckiego, „Studia Płockie", 1980, t. 8, s. 169-177.

Nir R., Stanowisko biskupa Andrzeja Krzyckiego wobec luteranizmu, „Studia Płockie”, 1981, t. 9, s. 73-85.

Nitecki P., Krzycki Andrzej (1481-1537), w: Biskupi Kościoła w Polsce w latach 965-1999: stownik biograficzny, Warszawa 2000, k. 232.

Nitecki P., Wolski-Dunin Piotr (1530-1590), w: Biskupi Kościoła w Polsce w latach 965-1999: stownik biograficzny, Warszawa 2000, k. 493.

Nitecki P., Załuski Andrzej Stanisław (1695-1758), w: Biskupi Kościoła w Polsce w latach 965-1999: słownik biograficzny, Warszawa 2000, k. 506.

Rojewski A., Formacja duchowieństwa archidiakonatu dobrzyńskiego w latach 1597-1609 i jej wptyw na przyjęcie posoborowej liturgii, „Studia Płockie”, 1976, t. 4, s. 23-54.

Rojewski A., Stan obiektów kulturowych i ich adaptacja do wymogów reformy trydenckiej $w$ archidiakonacie dobrzyńskim w latach 1597-1609, „Studia Płockie”, 1980, t. 8, s. 179-213.

Samsonowicz H., Supruniuk A., Dzieje polityczne (połowa XIV-początek XVIw.), w: Dzieje Mazowsza, t. 1, red. H. Samsonowicz, Pułtusk 2006, s. 257-338.

Schramm G., Problem reformacji w Warszawie w XVI wieku, „Przegląd Historyczny”, 1963, z. 4, s. 557-571.

Sobol B., O zaginionym druku mazowieckiego dekretu przeciwko luteranom z 1525 r., „Przegląd Historyczny", 1959, t. 50, z. 1, s. 81-85.

Sołtan A., Książka innowiercza na Mazowszu płockim w świetle akt kapituły płockiej z lat 1547-1552, „Rocznik Mazowiecki”, 15/2003, s. 27-34.

Strzebmosz T., Tumult warszawski, Warszawa 1959.

Strzelecki A., Baranowski Wojciech (1548-1615), w: PSB, t. 1, red. W. Konopczyński, Kraków 1935 s. 286-289.

Surmacz W.J., Ostatni synod płocki w Polsce przedrozbiorowej, „Studia Płockie”, 1976, t. 4, s. 145-184.

Urban W., Reformacja na Mazowszu, „Notatki Płockie”, 1985, nr 2, s. 24-27.

Wiśniowski E., Diecezja płocka u progu czasów nowożytnych, „Studia Płockie”, 1975, t. 3, s. $119-151$.

Woźniakowa M., Noskowski Andrzej (1492-1567), w: PSB, t. 23, red. E. Rostworowski, Wrocław-Warszawa-Kraków 1976, s. 218-223.

Wyszomirski T., Z przeszłości zboru protestanckiego w Wegrowie w XVII i XVIII wieku, „Odrodzenie i Reformacja”, 1959, t. 4, s. 137-155.

Zielińska Z., Poniatowski Michat Jerzy (1736-1794), w: PSB, t. 27, red. E. Rostworowski, Wrocław-Warszawa-Kraków 1983, s. 455-471.

Zygner L., Reformacja w Mławie - przyczynek do dziejów reformacji na Północnym Mazowszu, „Notatki Płockie”, 1995, nr 4, s. 19-20. 